\title{
BETWEEN MOTHERLAND AND FATHERLAND: DIASPORA, PILGRIMAGE AND THE SPIRITUALIZATION OF SACRIFICE IN PHILO OF ALEXANDRIA ${ }^{1}$
}

\author{
Andrea Lieber \\ Dickinson College
}

The concept of "diaspora" is used so frequently in the discourse of Jewish studies that to invoke it seems nearly cliché. Scholars of Jewish history have long been occupied with the project of unpacking the complexity of Jewish diasporic identity. And yet this very feature of Jewish experience that has for decades been taken for granted as a basic fact in the study of Judaism and Jewish culture, has of late received a good deal of attention in scholarly circles outside Jewish studies." "Diaspora" has emerged as a category of critical analysis that is embraced and applied not just to the case of the Jews, but to other dispersed populations as well. In the inaugural issue of the journal Diapsora: A Fournal of Transnational Studies, its editor Khachig Tölölyan wrote in 1991 that "diasporas are the exemplary communities of the transnational movement" and noted that diaspora now can be used to talk about a whole host of border-crossing identities: immigrant, expatriate, refugee, guest-worker, exile community, overseas community, ethnic community. ${ }^{3}$ In that same volume, William Safran noted that

${ }^{1}$ Betsy Halpern-Amaru was my teacher and mentor at Vassar College. I learned my first words of Hebrew in her courses, where she also introduced me to the work of Philo and the rich world of Jewish antiquity. It is with great admiration and profound gratitude that I dedicate this essay to her.

${ }^{2}$ Within Jewish studies, there are a few scholars whose work is concerned with bridging contemporary diaspora studies and Jewish studies. Some notable examples are Henry Goldschmidt, "Crown Heights is the Center of the World": Reterritorializing a Jewish Diaspora," Diaspora 9:1 (2000): 83-106; Jonathan Boyarin and Daniel Boyarin, Powers of Diaspora: Two Essays on the Relevance of Fewish Culture (Minneapolis: University of Minnesota Press, 2002); Alanna Cooper, "Conceptualizing Diaspora: Tales of Jewish Travelers in search of the Lost Tribes," A7S Review 30:1 (2006): 95-117; ibid., "Reconsidering the Tale of Rabbi Yosef Maman and the Bukharan Jewish Diaspora," Fereish Social Studies 10:2 (2004): 80-115. Particularly relevant to the present study is John M. G. Barclay, Negotiating Diaspora: Fewish Strategies in the Roman Empire (London and New York: T\&T Clark International, 2004).

${ }^{3}$ Khachig Tölölyan, "The Nation State and its Others: In Lieu of a Preface," Diaspora 1(1): 3 . 
diaspora is used as a metaphoric designation in much the same way that "ghetto" has come to designate all kinds of crowded, constricted and disprivileged urban environments and "holocaust" has come to be applied to all kinds of mass murder. ${ }^{4}$

It is fascinating that the Jews, in many respects the paradigmantic "other," have of late become so definitive of global cultural experience. Jonathan Boyarin and Daniel Boyarin, in their recent book, Powers of Diaspora, refer to this phenomenon when they suggest that a critical privileging of the term "diaspora" means understanding diaspora as a "normal" situation rather than a negative symptom of disorder. The permeability of boundaries and the "decenteredness" that typifies contemporary transnational reality has ironically come to resemble the worlds in which Jews have lived for centuries, and the very feature of Jewish society that once marked Jewish difference is now normative. Indeed, the way in which contemporary diasporas (and diaspora theorists) have come to challenge the viability of the modern nationstate echoes, in many respects, the very discourse employed by those enlightenment writers concerned with the Jews' place in the emerging modern European state.

Applying contemporary diaspora theory to the study of Jewish antiquity is problematic because so much of that discourse is couched in post-colonialism and a liberal critique of the nation-state. Can the insights of an interdisciplinary diaspora studies be applied to the study of Jewish communities that antedate the birth of the modern nationalism? Although contemporary diaspora studies often look to ancient Jewish civilization as an exemplary case, the most notable example being James Clifford's use of Goitein's "Geniza World," depicted in his master work $A$ Mediterranean Society, ${ }^{6}$ scholars are just beginning to read ancient diasporas through the lens of contemporary diasporas. As noted by John Barclay in his introduction to Negotiating Diaspora: Jewish Strategies in the Roman Empire, a recent volume which uses contemporary "diaspora" theory as a starting point for thinking about Jews in the Roman world, certain motifs central to post-colonial and diaspora studies, such as 'cultural hybridity' and 'double identities' are

\footnotetext{
${ }^{4}$ William Safran, "Diasporas in Modern Societies: Myths of Homeland and Return," Diaspora 1(1): 83-99.

5 James Clifford, "Diasporas," Cultural Anthropology 9 (1994): 302-308.

${ }^{6}$ S. D. Goitein, A Mediterranean Society: The Fewish Communities of the Arab World as Portrayed in the Cairo Geniza (6 vols.; Berkeley: University of California Press, 1967).
} 
very helpful concepts in analyzing Jewish life in the Greco-Roman era. In what follows, I suggest that reading antiquity through the lens of contemporary diasporas can reveal a more nuanced appreciation for the complexity of ancient diasporic existence.

\section{Philo's Diasporic Consciousness}

Philo is the quintessential voice of the Jewish diaspora in antiquity. Born approximately 20 C.E. to a prominent family in Alexandria (which was home to a diaspora Jewish community that was already centuries old), Philo is often depicted as a thinker who consciously sought to wed the divergent traditions of Hellenism on the one hand and Judaism on the other. Whether Philo's syncretism reflects a conscious process of selfdefinition or a more organically blended synthesis, ${ }^{7}$ his work provides the classic paradigm of Hellenistic-Jewish intellectual life.

Did Philo understand "diaspora" as a condition of oppression or disempowerment? A close reading of several key texts suggests that Philo did not. In fact, in what follows, I contend that Philo consistently attaches a positive valence to the Jewish dispersion, and in this respect develops a theology of diaspora that actually legitimates Jewish settlement in diverse locations. This is accomplished on the one hand by the use of Greek colonial language to refer to the Jewish dispersion, and on the other hand by his reading the religious acts of pilgrimage and sacrifice as rituals that are performed on a higher level in foreign lands. In this way, Philo affirms a diasporic consciousness that sees the Jews' dispersion as a mark of moral and spiritual superiority.

While some Jewish Hellenistic, and even earlier Persian sources, such as the canonical books of Ezra and Nehemiah, have a clearly developed theology about land and loss of land (we lost the homeland because of sin, which led to our exile, and through repentance we will be returned to the homeland), Philo's writing presents a distinct departure from that theological worldview. In fact, although Philo often idealizes Jerusalem,

${ }^{7}$ On this issue see Betsy Halpern-Amaru, Rewriting the Bible: Land and Covenant in Post-Biblical Fewish Literature (Valley Forge, PA: Trinity Press International, 1994); Isaiah Gafni, Land, Center and Diaspora: Jewish Constructs in Late Antiquity, (Sheffield: Sheffield Academic Press, 1997); Peder Borgen, "Philo of Alexandria" in Jewish Writings of the Second Temple Period: Apocrypha, Pseudepigrapha, Qumran, Sectarian Writings, Philo, Fosephus (ed. Michael Stone; CRINT 2; Philadelphia: Fortress Press, 1984), 233-282. 
he also frequently provides what appear to be rationalizations to account for and justify the Jews' diasporic condition. ${ }^{8}$

One of the most striking of Philo's strategies in this regard is his casting the relationship between Jerusalem and diaspora cities such as Alexandria in the language of Greek colonization. ${ }^{9}$ Twice in his extant writings, Philo states that the Jews consider Jerusalem to be their

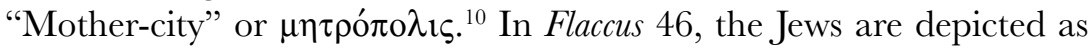
"too large" a people to be contained by one land:

For so populous are the Jews that no one country can hold them, and therefore they settle in very many of the most prosperous countries in Europe and Asia both in the islands and on the mainland, and while they hold the Holy City where stands the sacred Temple of the most high God to be their mother city ( $\mu \eta \tau \rho o ́ \pi \mathrm{o} \lambda \mathrm{is})$, yet those which are theirs by inheritance from their fathers, grandfathers, and ancestors even farther back, are in each case accounted by them to be their fatherland ( $\pi \alpha \tau \rho 1 \delta \alpha \varsigma$ ) in which they were born and reared, while to some of them they have come at the time of their foundation as immigrants to the satisfaction of the founders. ${ }^{11}$

Philo's use of colonial language fully turns the Jewish diaspora on its head. Instead of the result of foreign domination or disempowerment, the language of colonization suggests that Jewish settlement outside of Palestine is intentional and a mark of strength. Philo's claim is that the Jews are too numerous to be contained by one country, completely erasing the experience of forced expulsion from his history.

${ }^{8}$ A great deal has been written on Philo's relationship to Jerusalem. Of specific relevance to this study are Y. Amir, "Philo's Version of Pilgrimage to Jerusalem," in Die Hellenistische Gestalt des fudentums bei Philon von Alexandrien (Neukirchen-Vluyn: Neukirchener Verlag, 1983), 52-64; Betsy Halpern-Amaru, "Land Theology in Philo and Josephus," in The Land of Israel: Fereish Perspectives (ed. L. A. Hoffman; Notre Dame: University of Notre Dame Press, 1986), 65-93; I. Heinemann, "The Relationship between the Jewish People and their Land in Hellensitic Jewish Literature," Zion 13-14 (1948-49): 1-9 (Hebrew); H. J. Klauck, "Die Heilige Stadt. Jerusalem bei Philo und Lukas," Kairos 28 (1986): 129-136; W. C. van Unnik, Das Selbstverständnis der jüdischen Diaspora in der hellenistischen-røomischen Zeit (AGJU 17; Leiden: Brill, 1993).

9 John Graham, Colony and Mother City in Ancient Greece (2nd ed.; Chicago: Ares, 1983); Irad Malkin, Relgion and Colonization in Ancient Greece (Leiden: Brill, 1987).

${ }^{10}$ Philo's use of this term has received a great deal of scholarly attention. See van Unnik, 136; Amir, 53-55; Borgen, 269; A. Kasher, "Jerusalem as a 'Metropolis' in Philo's National Consciousness," Cathedra 11 (1979): 45-56; M. Niehoff, Philo on Jewish Identity and Culture (Tübingen: Mohr-Siebeck, 2001), 17-44. See also the recent study by Sarah Pearce, "Jerusalem as Mother City in the Writings of Philo of Alexandria," in Negotiating Diaspora (ed. J. Barclay; T\&T Clark/Continuum, 2004), 19-36.

${ }_{11}$ All translations excerpted from Colson, et al. Philo, 10 vols.; LCL; Cambridge, MA: Harvard University Press, 1990). 
In formulating his "double identity" Philo chooses the genealogical metaphors of "motherland and fatherland" to articulate dual parentage. In a similar passage from the Legatio ad Gaium, Philo writes:

While [the holy city] is my native city ( $\pi \alpha \tau \rho i \varsigma)$ she is also the mother city ( $\mu \eta \tau \rho o ́ \pi 0 \lambda 1 \varsigma)$ not of one country Judaea but of most of the others in virtue of the colonies ( $\dot{\alpha} \pi$ oเкíal) sent out at divers [sic] times to the neighboring lands.... And not only are the mainlands full of Jewish colonies ( $\dot{\alpha} \pi$ oıkíaı) but also the most highly esteemed of the islands, Euboea, Cyprus and Crete. ${ }^{12}$

Although Philo refers here to Jerusalem as both $\pi \alpha \tau$ pí and $\mu \eta \tau \rho o \pi o ́ \lambda ı$, he refers to Jewish settlements abroad as colonies $\dot{\alpha} \pi$ oıkí $\alpha$. Philo boasts of the fine cities and islands where Jews dwell. Although it is not a text that employs explicit colonial language, Philo's discussion of offering first fruits in Spec. 1:77-78 expresses similar pride in the esteemed places Jews have settled:

As the nation is very populous, the offerings of first-fruits are naturally very abundant. In fact, practically in every city there are banking places for the holy money where people regularly come and give their offerings. And at stated times there are appointed to carry the sacred tribute envoys selected on their merits, from every city those of highest repute, under whose conduct the hopes of each and all will travel safely.

In a recent analysis of this motif, Sarah Pearce suggests (in opposition to the majority of earlier scholarship on this theme) that Philo's use of colonial language reflects his attempt to assert the importance of the diaspora cities to Jewish identity. While earlier scholars have read Philo's language as a means of emphasizing the centrality of Jerusalem or defending the Jews' continued allegiance to the Temple there, Pearce argues that in calling diaspora cities "colonies" Philo is actually drawing on a tradition already evidenced in the Septuagint in which Zion is called $\mu \eta \tau \rho o ́ \pi о \lambda ı \varsigma$ (Is. 1.26), and the hebrew terms for diaspora communities (galut, golah) are typically translated with the Greek word used to refer to a colony $(\dot{\alpha} \pi$ oเкí $\alpha){ }^{13}$ Pearce concludes that, for Philo, "there is no tension between the notion of Jerusalem as mother-city and Alexandria as home." 14

12 Legatio 281-2.

${ }_{13}$ Pearce, $32-35$.

${ }_{14}$ Pearce, 36. 
Building on Pearce's thorough analysis of this motif in Philo's work, I am interested in probing the gendered dimension of the colonial language employed by Philo. In theorizing the Jewish diaspora Daniel Boyarin has argued that the diasporic condition is a feminized condition, one that challenges and subverts the phallic construction of nationalism. In the texts cited above, Philo also genders the Jewish diaspora through a genealogical metaphor, with homeland identified as "Mother" city and diasporic identity affiliated with the patriline - the fatherland. ${ }^{15}$ Rather than viewing diaspora as a result of domination and disempowerment, the Jews according to Philo are "too large" to be contained in one land - which is also perhaps an image of masculinity. Rather than a mark of weakness, the fact that Jews live spread out among distant lands is a sign of their virility. Philo thus casts the Jews' dispersion in terms of strength - perhaps as a rhetorical move to suggest that the Jewish diaspora, rather than an outcome of political disempowerment, is actually analogous to the conscious expansionist process of colonization.

\section{Pilgrimage}

In addition to Jewish migration from Jerusalem, Philo was also interested in Jewish movement toward Jerusalem in the practice of ritual pilgrimage. The complexity of Philo's diasporic consciousness is further expressed in his ambivalent attitude toward this rite. ${ }^{16}$ As an Alexandrian Jew, Philo's daily experience of Judaism and Jewish worship was necessarily removed from the daily mechanics of the Temple cult in Jerusalem. Diaspora Jews participated in sacrificial rites vicariously through their contribution to a temple tax, used to purchase the public sacrifice, but also through pilgrimage to the revered city on the occasion of annual holidays. ${ }^{17}$ Philo's description of pilgrimage emphasizes the phenomenon

${ }^{15}$ Compare Conf. 77-78: For surely, when men found a colony ( $\dot{\alpha} \pi$ oเкí $\left.\alpha v\right)$, the land which receives them becomes their fatherland $(\pi \alpha \tau \rho i \varsigma)$ instead of the mother-city ( $\mu \eta \tau \rho$ ó $\pi \mathrm{o} \lambda \mathrm{i} \varsigma$ ), but to the traveler abroad the land which sent him forth is the mother to whom he yearns to return.

16 See Harry A. Wolfson, Philo: Foundations of Religious Philosophy in Judaism, Christianity and Islam (2 vols.; Cambridge: Harvard University Press, 1947), 2:242-48.

17 Provid. 2.64 (Aucher 2. 107); See Wolfson, Philo, 241; E. R. Goodenough, By Light, Light (New Haven: Yale University Press, 1935); Emile Schürer, The History of the 
as an out-of-the-ordinary event; while presenting extreme hardship, it is one that reaps great benefits. Indeed, the willingness to endure pilgrimage is testimony to one's spiritual authenticity, and the cultivation of such discipline is understood by Philo as one of the purposes of the centralized Jerusalem cult:

[Moses] provided that there should not be temples built either in many places or many in the same place, for he judged that since God is one, there should be also only one temple. Further, he does not consent to those who wish to perform the rites in their houses, but bids them rise up from the ends of the earth and come to this temple. In this way he also applies the severest test to their dispositions. For one who is not going to sacrifice in a religious spirit would never bring himself to leave his country and his friends and kinsfolk and sojourn in a strange land, but clearly it must be the stronger attraction of piety which leads him to endure separation from his most familiar and dearest friends who form as it were a single whole with himself. ${ }^{18}$

Rather than worship at local shrines, God requires individuals to "rise up from the ends of the earth and come to the temple" to worship God as one people. Thus, the centralization of Jewish temple worship reflects the unity of God, and even foreshadows the unity of the exiled Jewish people.

The existence of a singular temple, and the necessity of pilgrimage to it, also nurtures proper spiritual discipline and checks the private will. According to this view, one must have genuine faith to journey from Alexandria to Jerusalem. Indeed, Philo emphasizes the difficulty of pilgrimage over the ease of local worship. The passage from Philo cited above reveals the perception of a sharp distance between Alexandrian Jewry and their kin living in the land of Israel. To embark on a pilgrimage in order to sacrifice entails a departure from "friends and kinsfolk" and a sojourning in a "strange land." Philo is rather dramatic in his phrasing in an effort to show what a great trial the pilgrimage presents. Kinsfolk are those who "form a single whole" and leaving to sacrifice is an extreme challenge. But according to Philo, there is a spiritual payoff. Upon arriving at the Jerusalem Temple, another type of communal unity is achieved among those who have journeyed from "the ends of the earth":

Fewish People in the Age of Fesus Christ (rev. and ed. by Geza Vermes and Fergus Millar; Edinburgh: T\&T Clark, 1973), III.1:586.

18 Spec. Leg. 1.67. 
Countless multitudes from countless cities come, some over land, others by sea, from east and west and north and south at every feast. They take the temple for their port as a general haven and safe refuge from the bustle and great turmoil of life, and there they seek to find calm weather, and, released from the cares whose yoke has been heavy upon them from their earliest years, to enjoy a brief breathing space in scenes of genial cheerfulness. Thus filled with comfortable hopes they devote the leisure, as is their bounded duty, to holiness and the honoring of God. Friendships are formed between those who hitherto knew not each other, and the sacrifices and libations are the occasion of reciprocity of feeling and constitute the surest pledge that all are of one mind. ${ }^{19}$

The scene described in the above passage is remarkable in its resemblance to an eschatological scene. Pilgrimage to the temple of Jerusalem created unity among Jews from diverse locales. In the service of God, they affirmed their like-mindedness and shared sacrificial food and drink. It appears that Philo imagines this phenomenon as a preview of Israel's future, when all Jews would be united to sacrifice again in Jerusalem. ${ }^{20}$ The ingathering of the exiles was one of the signal features of the messianic age according to Philo, ${ }^{21}$ whose ideas on the subject seem to rely on exegetical interpretations of Isaiah 2 or Micah 4. Philo seems to be hinting that pilgrimage is in fact a model for his eschatological vision. In Philo's description of pilgrimage, the exiles gather, worship God with sacrifices and celebrate their unity as a people in the service of God by sharing food and drink.

In advocating sacrificial worship at a centralized shrine, Philo's work reflects the perspective of the biblical writers of Deuteronomy and Chronicles. Yet his insistence upon centralized sacrifice may also be influenced by Greek thought. Book X of Plato's Laws deals with hypothetical motives for impious behavior among citizens of an ideal polis. One source of impiety presented by Plato is the belief that the gods might be won over by "the cajoling of offerings and prayers." 22

19 Spec. Leg. 1.70.

${ }^{20}$ Ellen B. Birnbaum, The Place of Judaism in Philo's Thought (Atlanta: Scholars Press, 1996), see especially Chapter 3, "Israel and the Ones Who Can See."

${ }_{21}$ Wolfson, Philo, 408. Ingathering of the exiles, national prosperity in the Jewish homeland and peace among all human beings and between human and animal life were the three features of the messianic age in Philo. See Praem 29, 165, 168.

${ }^{22}$ Plato Laws 10. 882b. Text from The Laws, trans., A. E. Taylor in Plato: The Collected Dialogues (ed. E. Hamilton and H. Cairnes; Princeton: Princeton University Press, 1961), 1225-1513. The other two forms of impiety were 1) outright rejection of the belief that Gods exist at all, and 2) the belief that Gods do exist, but are indifferent to the plight of humanity. 
The interlocutors of this dialogue seek to refute those who believe in divine venality, and in the end, set up legislation designed to curb such impiety:

We must frame a law applicable to all these offenders alike, and designed to alleviate the sin of most of them against religion in word or act - to say nothing of the folly of the sinners - by the prohibition of illegal ceremonial. In fact the following law should be enacted for all cases without exception. No man shall possess a shrine in his private house; when a man feels himself moved to offer sacrifice, he shall go to the public temples for that purpose and deliver his offerings to the priests of either sex whose business it is to consecrate them. He may join with himself in the prayers any person whose company he may desire. ${ }^{23}$

No individual is permitted to have a private altar, and if moved to offer sacrifice, must go to the public temple and make the offering via the priest. Plato explains that the law is necessary because people, particularly women and the sick, are often prompted by fear into making sacrificial offerings. In addition, those seeking visions or advice are prone to sacrifice according to their own will, whenever and wherever they want. Plato's ban on private altars would, he believed, promote authenticity among worshippers. The discussion continues as follows:

[The Law] prevents fraud in this matter itself, from setting up shrines and altars in their own houses, under the delusion that they are winning the privy favor of heaven by offerings and prayers, thus indefinitely aggravating their criminality and bringing guilt before God on themselves and the better men who tolerate their conduct, until the whole community reaps the harvest of their impiety - as in a sense it deserves... the enactment [of the legislator] shall run thus: No citizen is to possess a shrine in his private dwelling house; ... Any person proved guilty of a sin against piety... whether by dedicating a shrine on private ground or by doing sacrifice to any gods whatsoever in public, shall suffer death for doing sacrifice in a state of defilement. ${ }^{24}$

The private impiety of an individual who sacrifices at a private shrine has the potential to undermine the piety of the community at large. As such, private altars are not merely discouraged, but banned, lest the whole city be brought to sin.

${ }^{23}$ Laws, 10. 909d-910b.

${ }^{24}$ Laws, 10. 910c-d. 


\section{Sacrifice}

Philo's writing reveals a great deal of ambivalence about sacrifice; the majority of his references to the subject involve an extreme "spiritualization" of the rite. In fact, in most places where Philo interprets texts dealing with the cult, he allegorizes to the extent that the literal components of sacrificial practice are actually devalued in favor of the quality of intention that underlies them. Indeed, it is the inward condition of the soul for Philo that constitutes the true sacrifice.

Valentin Nikiprowetzky has argued that Philo, in his spiritualization of the cult, must be understood as a thinker situated at the crossroads of the biblical and Greek philosophical doctrines of sacrifice. As a Jew ensconced in the Hellenistic world, Philo was heir to polemic against the practice of sacrifice from both traditional Jewish and classical Greek perspectives. We saw above his resonance with Greek and Deuteronomic thought in Philo's advocating of a centralized cult. But in his deeper reflection on the meaning of sacrifice, Philo presents a perspective that lies rather someplace between the radical prophetic polemic against sacrifice attested in the Bible ${ }^{25}$ and the stance against blood-rites advocated by the Pythagorean and Neo-Pythagorean philosophical schools. ${ }^{26}$ The biblical polemic presented contemporary temple-sacrifice as corrupt, and looked toward the "messianic" future for the practice of undefiled and true sacrifice. ${ }^{27}$ The Pythagoreans abhorred blood sacrifice on the grounds that it was wrong to slaughter ritually an animal victim. Pythagoras' condemnation of animal sacrifice was rooted in the belief that human and animal lives are intimately connected. Among the

${ }^{25}$ Valentin Nikiprowetzky, "Spiritualisation et Culte Sacrificiel chez philon d'Alexandrie," Semitica 16 (1967): 97-116: "L'enseignement de Philon est situé au carrefour, on l'a dit, de la doctrine scripturairee et de la doctrine philosophique des sacrifices. L'une et l'autre se reflètent donc dans ceux de ses textes qui concernent ce point particulier de théologie" (99).

${ }^{26}$ Richard D. McKirahan, Jr., Philosophy Before Socrates (Indianapolis: Hackett, 1994), 88-89. The Pythagoreans viewed killing anything as a great offense. All living things are related, according to the Pythagorean system, thus any killing is the equivalent of murder.

27 "O LORD open my lips, and let my mouth declare your praise. You do not want me to bring sacrifices; you do not desire burnt offerings; true sacrifice to God is a contrite spirit; God you willnot despise a contrite and crushed heart. May it please you to make Zion prosper; rebuild the walls of Jerusalem. Then you will want sacrifices offered in righteousness, burnt and whole offerings; then bulls will be offered on your altar." Ps. 51:17-21. 
Pythagoreans, the belief in metempsychosis, the passing of a human soul into another human or animal life, fostered a belief that the taking of animal life for blood sacrifice was morally wrong. ${ }^{28}$

Philo's view is not as extreme as that of the biblical prophets in condemning contemporary sacrifice as corrupt, nor did he advocate the cessation of blood sacrifice as did the Pythagoreans. Rather, he accepts sacrifice and pilgrimage as legitimate forms of worship which have their own merit yet, nonetheless, devalues such practice in relation to the allegorical significance he attaches to the sacrificial cult. Thus, Philo reads the prescriptions of Leviticus concerning the cult in a "spiritualized" manner: "... what is precious in the sight of God is not the number of victims immolated but the true purity of a rational spirit in him who makes the sacrifice. ${ }^{, 29} \mathrm{~A}$ few lines later in the same text we read, "....He who intends to sacrifice must consider not whether the victim is unblemished but whether his own mind stands free from defect and imperfection." ${ }^{30}$ His interpretation focuses on the interior disposition of the person presenting the offering and in many cases the interior aspect becomes the whole of the rite; the halakhic particularities of the cult are irrelevant. Philo turns his attention to the quality of the soul in the performance of sacrifice, and even goes so far as to associate explicitly the soul who brings the sacrificial offering with the sacrificial victim itself. Thus every aspect of the actual rite of sacrifice takes on a deepened, philosophical meaning which is presented as embodying the ritual's true, if hidden, significance. Indeed, the material offering is only the exterior expression of an internal condition. ${ }^{31}$ Philo emphasizes the need for purity of the "heart" rather than the technical purity of sacrificial offerings. ${ }^{32}$

While the Jerusalem Temple occupies an important place in Philo's understanding of Judaism and the Jewish people, his radical spiritualization of the cult has been read as an effort to find daily moral and spiritual meaning in the prescriptions surrounding the cult. Israel, which for Philo is the nation who "sees God," is also a nation of priests. But what is the meaning of a national priesthood that lives apart from the

\footnotetext{
28 Nikiprowetzky, "Spiritualization," 13.

29 Spec. Leg. 1.277.

Spec. Leg. 1.277. See Saul Lieberman, Hellenism in Jewish Palestine (New York: JTSA, 1962), 153-163.

31 Nikiprowetzky, "Spiritualization," 101.

32 Cf. Hosea 6.6: "For I desire goodness, not sacrifice; obedience to God, rather than burnt offerings."
} 
national temple? Philo's spiritualization of the cult allows for the priesthood itself to become spiritualized and removed from the apparatus of temple sacrifice. Priestly status becomes a disciplined, moral and spiritual ideal attainable by all Israel. In this respect, Philo's re-reading of sacrifice along with his insistence upon a centralized shrine, enables a truer form of cultic worship to be practiced in a diaspora setting.

Interpreting the numerous prescriptions in the Septuagint ${ }^{33}$ text, Philo attaches symbolic significance to the multiple components of the sacrificial rite ${ }^{34}$ Every detail of the cult is spiritualized as Philo transforms sacrifice into a contemplative journey. His references to sacrifice and the temple are scattered throughout his works, but the most extensive and detailed treatments are in Questions and Answerson Exodus, ${ }^{35}$ where he describes point-by-point the features of the tabernacle, and in On the Special Laws, where he gives lengthy exegetical commentary on Leviticus. The entire geography of the Temple, as described in the biblical text, is fully allegorized. The temple itself symbolizes the cosmic meeting place of the sensible and intelligible worlds, and sacrifice becomes a contemplative activity by means of which these two aspects of reality are neatly bridged. The ark is a symbol of the incorporeal world, ${ }^{36}$ and the table adjacent to it symbolizes the sense-perceptible world. ${ }^{37}$

${ }^{33}$ It is important to note that the Septuagint itself allegorizes somewhat in its translation of some of the technical cultic apparatus. For example, the urim and thummim, are translated as deylosis kai aleytheia ("manifestation" and "truth") or sapheyneia (distinctness, perspicuity) kai aleytheia (Philo: Spec. Leg. 3.132,140; IV.69; Mos. 2.113, 128-29). Thus, it is possible that Philo's own allegories were based upon similar ideas already circulating in Greek-Jewish culture.

${ }^{34}$ Philo employs allegory to "spiritualize" Jewish law as it is reflected in the text of the Septuagint. I use the term "spiritualize" to describe Philo's tendency to provide moral, ethical and philosophical explanations which constitute the deeper meaning of particular Biblical commandments, over and above his literal interpretation of those same texts. Philo reads the Bible on two levels: he reads contextually to provide a literal understanding of a text, but also reads symoblically, abstracting the message of a biblical passage beyond its context to arrive at its homiletical or moral significance. Philo frequently calls these two components of scripture the "body" and "soul" of a text.

${ }^{35} Q E$ is extant only in Armenian and Latin translations from the Greek. There are numerous Greek fragments, and I have provided relevent Greek text where it is available, but lack of an Urtext makes careful scrutiny of Philo's language in this document rather difficult. All texts cited in this chapter are from Ralph Marcus, Philo Supplements (2 vols.; LCL; Cambridge, MA: Harvard University Press, 1953). I have noted manusript variants where relevant.

${ }_{36}$ OE 2.59 .

37 QE 2.69. Philo also attaches cosmic significance to many other pieces of the tabernacle's furnishings. The bowls on the branches of the menorah stand for zodiacal signs ( $Q E$ 2.76); the mixing-bowls on the lampstand represent the seasons of the year (QE 2.77). The lampstand in general seems to be associated with heavenly luminaries. See $Q E$ 2.78-80. 
The four rings that are fit onto the ark, two on each side, symbolize the division of the world into the sense-perceptible and the intelligible sides ${ }^{38}$ the cherubim are situated on two sides of the altar to indicate that the "bounds of the whole heaven and the world are fortified by the two highest guards," God's creative potency and God's ruling potency. ${ }^{39}$ The temple is the sacred topos where divine and human, intelligible and sensible worlds meet.

Philo holds that the Tabernacle (and by implication, the Temple) was constructed according to a heavenly archetype that was revealed to Moses when he ascended Sinai. Indeed, during this ascent, Moses was shown the pattern according to which the whole universe was made. ${ }^{40}$ The temple, which encases the boundary between the sensible and intelligible worlds, is a microcosm of the universe, but also a macrocosm of the individual soul. In Philo's words: "What is the meaning of the words, 'Thou shalt make (them) according to the pattern which has been shown to thee on the mountain'?41 Through the 'pattern' He again indicates the incorporeal heaven, the archetype of the sense-perceptible, for it is a visible pattern and impression and measure." ${ }^{22}$ The tabernacle is built on the model of the heavens. Indeed, the whole heaven is itself a temple of God. The true temple is the universe; the one crafted by human hands is a replica:

The highest, and in the truest sense the holy temple of God is, as we must believe, the whole universe, having for its sanctuary the most sacred part of all existence, even heaven, for its votive ornaments the stars, for its priests the angels who are servitors to his powers, unbodied souls, not compounds of rational and irrational nature, as ours are, but with the irrational eliminated, all mind through and through, pure intelligence's, in the likeness of the monad. There is also the temple made by hands; for it was right that no check should be given to the forwardness of those who pay their tribute to piety and desire by means of sacrifices either to give thanks for the blessings that befall them or to ask for pardon and fogginess of their sins. ${ }^{43}$

${ }^{38}$ QE 2.56 .

39 QE 2.64

${ }^{40} Q E$ 2. 52: "For indeed it was indeed proper and fitting to reveal to an intelligent man the forms of intelligible things and the measures of all things in accordiance with which the world was made.

${ }^{41}$ See Leg. All 3.102, where Philo uses this same verse to contrast Moses, the artificer of archetypes, with Bezalel, artificer of the objects made in accordance with the archetype.

${ }^{42} Q E 2.82$.

43 Compare Hebrews 5-9, where the tabernacle represents a sketch or replica of the heavens, which is depicted as the true temple. Both Philo and the author of Hebrews 
Consequently, the heavenly temple is administered by the unbodied angels, and the material temple is administered by priests. Just as the temple is a microcosm of the universe, so it is a macrocosm of the human soul. The high priest dons the tunic, which represents heaven. He literally "puts on" the cosmos to represent the unity of humanity with the whole heaven:

For there are, as is evident, two temples of God: one of them this universe in which there is also as High Priest his first born, the divine word, and the other rational soul, whose priest is the real Man; the outward and visible image of whom is he who offers the prayers and sacrifices handed down from our fathers, to whom it has been committed to wear the aforesaid tunic, which is a copy and replica of the whole heaven, the intention of this being that the universe may join with man in the holy rites and man with the universe. ${ }^{44}$

The temple itself is a mediator between human and divine reality, and the priest though sacrifice, enacts this drama of mediation.

But the attire of the high priest during temple service is more than symbolic. According to Philo, the priest, upon entering the holy of holies undergoes a profound ontological transformation: his body and soul detach from one another as he mediates between heaven and earth:

... according to Moses, the priest when he goes into the holy of holies 'will not be a man until he comes out' (Lev 16.17); ${ }^{45}$ no man, that is, in the movements of his soul though in the bodily sense he is still a man. For when the mind is ministering to God in purity, it is not human, but divine. But when it ministers to ought that is human, it turns its course and descending from heaven, or rather falling to earth, comes forth, even though his body still remains within. Most rightly then is it said, 'He led him outside,' outside of the prison houses of the body, of the lairs where the senses lurk, of the sophistries of deceitful word and thought; above all He led him out of himself ... ${ }^{46}$

The temple is the sacred locus for the intersection of God and humanity, or to use Philo's terminology, it is where the intelligible and sensible

credit Moses with the building of the tabernacle according to a heavenly paradigm, revealed to him by God. S. G. Sowers, The Hermeneutics of Philo and Hebrewes: A Comparison of the Interpretation of the Old Testament in Philo Fudaeus and the Epistle to the Hebrewes (Zurich: Müller, 1965).

${ }^{44}$ De Somn. 1. 215.

45 The biblical passage, of course, refers to the fact that no other man will enter the holy of holies until the priest comes out. "When he goes in to make expiation in the shrine, nobody else shall be in the tent of meeting until he comes out" (Lev. 16:17).

${ }^{46}$ Heir, 84-85. 
realms meet. Traversing the threshold between the divine and human realms, the priest exists in a liminal state as his soul is "led outside" of its sensible body. The high priest, who navigates this precarious boundary, is frequently described in such "mystical" terms as a semi-divine figure. ${ }^{47}$ Indeed, his journey into the inner sanctum of the temple is a journey to another place, one that transcends physical reality. The efficacy of his sacrificial offerings is dependent upon his openness to the psychic transformation he must undergo when he enters the inner sanctum of the temple, which for Philo, symbolizes the unchanging realm of pure intellect. The priestly robe is just one symbol of his mystical significance. Describing in detail the vestment of the high priest, Philo writes of the garment:

Such is the form in which the sacred vesture was designed, a copy of the universe, a piece of work of marvelous beauty to the eye and the mind. To the eye it presents a most amazing appearance transcending any woven work that we possess in variety and costliness, to the mind the philosophical conceptions which its parts suggest. For it expresses the wish first that the high priest should have in evidence upon him an image of the All, that so by constantly contemplating it he should render his own life worthy of the sum of things, secondly that in performing his holy office he should have the whole universe as his fellow ministrant. ${ }^{48}$

Wearing the mystical robe, the priest bears the image of "the All." The image is a reminder that he serves God as a representative of the whole universe ${ }^{49}$ The robe is a garment of mediation and in wearing it, the Priest is equivalent to the whole nation. A symbol of the transformation experienced by the priest at the culmination of the sacrificial rite is his change of garment as he enters the inner sanctum of the temple. He removes the luminous garment that symbolized the universe and instead puts on pure, white linen, "a figure of strong fiber, imperishableness, most radiant light: for fine linen is hard to tear, and is made from no

47 The relationship between priestly or anti-priestly polemic and the origin of messianic and mystical traditions has been treated by a number of scholars. See L. Baeck, The Pharisees and Other Essays (New York: Schocken Books, 1966); R. Elior, The Three Temples: On the Emergence of Jewish Mysticism (Oxford: Littman Library, 2004); Gruenwald, "From Priesthood to Messianism: The Anti-Priestly Polemic and the Messianic Factor," in Fishbane, ed., Messiah and Christos. On the mystical garment, see G. Scholem, Fewish Gnosticism, Merkabah Mysticism, and Talmudic Tradition (2nd ed.; New York: Jewish Theological Seminary of America, 1965), 56-64.

48 Spec. Leg. 1. 95.

${ }^{49}$ It is interesting to note Philo's universalizing spirit here. Sacrifice accomplishes redemption for all humanity, not just Jews. 
mortal creature, and moreover when carefully cleaned has a very brilliant luminous color." ${ }^{50}$ That the priest's garment is not made from animal skins is significant. Again, we are reminded of the Pythagorean distaste for blood sacrifice. The priest's own identity is bound up with that of the sacrificial offering. ${ }^{51}$

Philo is preoccupied with the soul of the priest and its proper condition for performing the sacrificial rites. The soul, in fact, becomes the central focus of his spiritualized cult. As the soul of the priest is viewed as a paradigm for the individual soul, Philo is able to transform sacrifice from a rite of the spiritual and political elite into a personal model for psychic discipline. ${ }^{52}$ Philo's spiritualization completely removes sacrifice from the actual cultic apparatus of the Jerusalem Temple. Indeed, it becomes a rite of the soul.

Philo describes the soul itself as the one true altar:

The true altar of God is the thankful soul of the Sage, compacted of perfect virtues unsevered and undivided, for no part of virtue is useless. On this soul-altar ( lit.: on it) the sacred light is ever burning and carefully kept unextinguished, and the light of the mind is wisdom, just as the darkness of the soul is folly. ${ }^{53}$

The actual temple altar is not the true altar. Rather, the wise soul focused on divine knowledge is the shrine and he cultivation of wisdom within the soul is the truest offering:

What is the meaning of the words, 'Thou shalt make for me a sanctuary, and I shall appear among you'?... If however, thou art worthily initiated and canst become an animate shrine of the Father, then instead of having closed eyes, thou wilt see the First Cause [var. First things] and in wakefulness thou wilt cease from the deep sleep in which thou has been

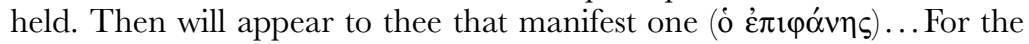

50 De Somn. 1. 216-217.

51 The concept of "bloodless sacrifice" is a major theme in the Gospel to the Hebrews. Philo's allegorizing of sacrifice is believed to have exerted strong influence upon the early fathers of the church. See Jean Laporte, "Sacrifice in Origen in Light of Philonic Models," in Origen of Alexandria: His World and His Legacy (ed. C. Kannengiesser and W. Peterson; Notre Dame: University of Notre Dame Press, 1988), 250ff.

52 Steven D. Fraade, "Ascetical Aspects of Ancient Judaism," in Fewish Spirituality from the Bible Through the Middle Ages (ed. Arthur Green; New York: Crossroad, 1987), 253-288; James Montgomery, "Ascetic Strains in Early Judaism," fBL 51 (1932):183213; Vincent Wimbush, Renunciation Towards Social Engineering (An Apologia for the Study of Ascenticism in Greco-Roman Antiquity) (OPIAC 8; Claremont: Institute for Antiquity and Christianity, n.d.).

53 Spec. Leg. 1.287-88. 
beginning and end of happiness is to be able to see God. But this cannot happen to him who has not made his soul, as I said before, a sanctuary and altogether a shrine of God. ${ }^{54}$

Every individual becomes a sanctuary, add altar and a priest. Philo's understanding endows those who contemplate noetic reality with a type of priestly ability. One whose soul is like an altar can see God and the secrets of creation. This text provides a vivid example of one of Philo's most extreme allegories of the cult. Philo spiritualizes the sacrificial process to such an extent here that he seems to describe a process that is almost entirely interior. Is Philo perhaps suggesting that true sacrifice is a contemplative experience that can be accessed without the temple and priestly apparatus? In this sense, Philo's allegory accomplishes a true democratization of the priesthood. ${ }^{55}$

\section{Conclusion}

Many scholars have assumed that it was lack of access to the temple, a result of persecutions expressed in texts such as Daniel or Ezekiel, that inspired tales of ascent to a heavenly temple and visions of a third, restored temple in the eschatological future. In Philo's time, however, the temple still stood, and remained an institution of symbolic importance in Philo's work. Thus, Philo's consistent allegorizing of the temple cult is curious, as the cult continued to function as a central religious institution in his day, and as discussed above, he continued to value pilgrimage as an important form of religious observance and communal solidarity.

Though the temple still functioned in Jerusalem, Philo chose to engage sacrifice through allegory, and thus transformed it into an interior-focused, contemplative rite. While Jerusalem might still have been the axis mundi, the place where heaven and earth meet, the place where the Jewish people will be restored to its unity, it was also, for Philo, not a place at all. Indeed, Philo's "Jerusalem" was a spiritual condition of psychic balance, a state of mind that was attainable in a unique way in diaspora. If we read Philo's allegorizing as an active attempt to affirm the "powers of diaspora" - to craft a diasporic identity founded

${ }^{54}$ QE 2.51.

${ }_{55}$ Martha Himmelfarb, Ascent to Heaven in Fewish and Christian Apocalypses (New York: Oxford, 1993). 
on national virility as well as superior moral virtue, then the theology of diaspora that emerges in Philo's writing is one that accords divine purpose to the status of exile. This divine purpose is not played out through the drama of sin and punishment, but rather in highlighting the ways in which the dispersion of the Jews conforms to, and perhaps even anticipates, the very ideals of ancient Greek colonization. This scenario bears a striking resemblance to Judaism's ironic history in the post-modern era - that after centuries of marginalization and difference, Judaism's transnational existence is now representative of the global norm. 